\title{
MODIFIKASI MESIN PENGUPAS KULIT KACANG TANAH
}

\author{
Riklan Tahapali ${ }^{1)}$, Romi Djafar ${ }^{2)}$, Yunita Djamalu ${ }^{3)}$ \\ ${ }^{1)}$ Mahasiswa Program Studi Mesin dan Peralatan Pertanian, Politeknik Gorontalo \\ ${ }^{2,3)}$ Dosen Program Studi Mesin dan Peralatan Pertanian, Politeknik Gorontalo
}

\begin{abstract}
ABSTRAK
Kacang tanah (Arachis hypogaea L.) merupakan salah satu tanaman legum yang mempunyai nilai ekonomi tinggi karena kandungan gizinya terutama protein dan lemak yang tinggi, namun produksi kacang tanah di Indonesia terus mengalami penurunan sehingga kebutuhan akan kacang tanah tidak terpenuhi.(Djatiharti et al., 2016). Di Provinsi Gorontalo khususnya di Kabupaten Gorontalo ini, produksi kacang tanah setiap tahun diperkirakan sekitar 521,30 ton per tahun, 43.441 ton per bulan, $1.448 \mathrm{~kg}$ per hari (Badan Pusat Statistik 2017). Disisi lain, untuk mengolah kacang tanah ini para petani masih menggunakan cara tradisional yang dianggap praktis meskipun tidak efektif dan efisien. Kondisi ini tentu sudah menjadi kebiasaan bagi para petani kacang tanah, karena belum ada konsep teknologi tepat guna didaerah ini sebagai solusi alternatif yang dianggap praktis. Para petani kacang tanah dalam proses pengupasan masih menggunakan cara tradisional yakni mengupas kacang tanah dengan cara dikupas dengan tangan secara manual, sehingga pengupasan kulit kacang tanah membutuhkan waktu yang lama. Disampig itu pengupasan kulit kacang tanah secara manual juga menimbulkan kebosanan pada tingkat kerja yang tinggi, Untuk mengatasi persoalan kulit kacang tanah tersebut maka diperlukan suatu mesin pengolahannya yaitu "Modifikasi Mesin Pengupas Kulit Kacang Tanah" dengan kapasitas 10,28 kg/jam. Dimaksud untuk membantu para petani khususnya petani kacang tanah untuk mempermudah dalam proses pengupasan kacang tanah. Setelah dilakukan perancangan mesin pengupas kacang tanah diperoleh dimensi dan ukuran mesin yang sesuai dengan standar yang ada seperti daya motor listrik yang digunakan, diameter poros yang digunakan, bagian-bagian alat seperti mata pisau satu dan mata pisau dua, saringan satu dan dua, dan pulley. Sehingga akan dihasilkan mesin pengupas kulit kacang tanah dengan biaya yang lebih efisien dan terjangkau dan hasil produksinya juga sesuai dengan yang diharapkan.
\end{abstract}

Kata Kunci : Kacang Tanah, Modifikasi, Saringan satu dan dua

\section{MODIFICATION OF PEANUT LEATHER MACHINE}

\begin{abstract}
Peanut (Arachis Hypogaea L.) is a plant that has high economic value because of its nutritional content, especially high protein and fat, but peanut production in Indonesia continues to decline so that the needs The groundnuts are not fulfilled. (Djatiharti et al., 2016). In Gorontalo Province especially in this Gorontalo Regency, peanut production every year is estimated at about 521.30 tons per year, 43,441 tons per month, 1,448 $\mathrm{kg}$ per day (Central statistics 2017). On the other hand, to cultivate these groundnuts farmers still use the traditional way that is considered practical although ineffective and efficient. This condition is certainly a habit for peanut farmers, because there is no concept of appropriate technology in this area as an alternative solution that is considered practical. The peanut farmers in the process of stripping still use the traditional way that is to peel peanuts by hand-peeled with the hands manually, so that peanut stripping takes a long time. Disampig It manual peanut Peel also raises boredom at a high level of work, to overcome the problem of peanut skin then it is required a processing machine is "modified peanut peel Machine Soil "with a capacity of $10.28 \mathrm{~kg} / \mathrm{h}$.
\end{abstract}


Intended to help farmers especially peanut farmers to facilitate the process of stripping groundnuts. After the design done the peanut Peeler machine obtained the dimensions and size of the machine that corresponds to the existing standard such as electric motor power used, the diameter of the shaft used, the tool parts such as the blade one and the blade Two, a sieve one and two, and a pulley. So that the peanut Peel machine will be produced with a more efficient and affordable cost and the results of the production also as expected.

Keywords: peanut, modification, sieve one and two

\section{PENDAHULUAN}

Kacang tanah (Arachis hypogaea L.) merupakan salah satu tanaman legum yang mempunyai nilai ekonomi tinggi karena kandungan gizinya terutama protein dan lemak yang tinggi, namun produksi kacang tanah di Indonesia terus mengalami penurunan sehingga kebutuhan akan kacang tanah tidak terpenuhi.(Djatiharti et al., 2016). Di Provinsi Gorontalo khususnya di Kabupaten Gorontalo ini, produksi kacang tanah setiap tahun diperkirakan sekitar 521,30 ton per tahun, 43.441 ton per bulan, $1.448 \mathrm{~kg}$ per hari (Badan Pusat Statistik 2017). Disisi lain, untuk mengolah kacang tanah ini para petani masih menggunakan cara tradisional yang dianggap praktis meskipun tidak efektif dan efisien. Kondisi ini tentu sudah menjadi kebiasaan bagi para petani kacang tanah, karena belum ada konsep teknologi tepat guna didaerah ini sebagai solusi alternatif yang dianggap praktis. Para petani kacang tanah dalam proses pengupasan masih menggunakan cara tradisional yakni mengupas kacang tanah dengan cara dikupas dengan tangan secara manual, sehingga pengupasan kulit kacang tanah membutuhkan waktu yang lama. Disampig itu pengupasan kulit kacang tanah secara manual juga menimbulkan kebosanan pada tingkat kerja yang tinggi, Untuk mengatasi persoalan kulit kacang tanah tersebut maka diperlukan suatu mesin pengolahannya yaitu mesin pengupas kulit kacang tanah

Pada dasarnya mesin pengupas kulit kacang tanah ini sudah ada di Provinsi Gorontalo khususnya di kampus Politeknik Gorontalo yang di rancang oleh Makatita Yuslanto pada tahun 2013, namun cara kerja mesin pengupas kulit kacang tersebut belum maksimal dikarenakan kulit kacang tanah dan biji kacang tanah masih jatuh bersamaan (tidak terpisah).
Di daerah Kabupaten Gorontalo paling banyak masyarakat penghasil kulit kacang tanah, sehingga pembuatan alat ini sangat dibutuhkan, selain untuk mempermudah proses pengupasan kulit kacang tanah juga dapat meningkatkan kapasitas pengupasan kulit kacang tanah.

Berdasarkan permasalahan yang ada maka penulis akan merancang mesin pengupas kulit kacang tanah yang dapat memisahkan kulit kacang tanah dengan daging kacang tanah dengan desain yang lebih optimal. Sehingga selain dapat menghemat waktu dan biaya produksi juga dapat menjadi solusi masyarakat dalam pengolahan kacang tanah yang lebih baik

\section{METODE PENELITIAN}

\section{Kebutuhan Alat Dan Bahan}

\section{$>$ Alat}

alat dan bahan yang akan di gunakan dalam pembuatan Pembuatan mesi pengupas kulit kacang tanah

1. Mesin Las

2. Mesin Bubut

3. Gerinda Potong

4. Tang Jepit

5. Masker Las

6. Sarung Tangan

7. Kertas Pasir Harus

8. Mesin Bor

9. Kunci Ring Pas

10. Mistar Baja

11. Sigmat Mitutoyo

12. Roll Meter

13. Palu Karet

Bahan

1. Besi Plat

2. Besi siku 

3. Pipa Besi
4. Besi Poros
5. Elektroda Las
6. Batu Gurinda Potong
7. Batu Gurinda Asah
8. Mata Gurinda Kikis
9. V-Blok
10. Pulley
11. Pilox

\section{HASIL DAN PEMBAHASAN}

\section{Hasil Rancangan Mesin Pengupas Kulit Kacang Tanah}

Hasil pembuatan mesin pengupas kulit kacang tanah dilakukan pada dilaboratorium Mesin Peralatan Pertanian (MPP). Gambar 4.1 menunjukkan mesin pengupas kulit kacang tanah menggunakan mesin listrik dengan tenaga 1400 $\mathrm{rpm}$ atau $1 / 4 \mathrm{hp}$ sebagai penggerak yang dapat memisakan biji kacang tanah dengan kulit kacang tanah sebagai berikut :

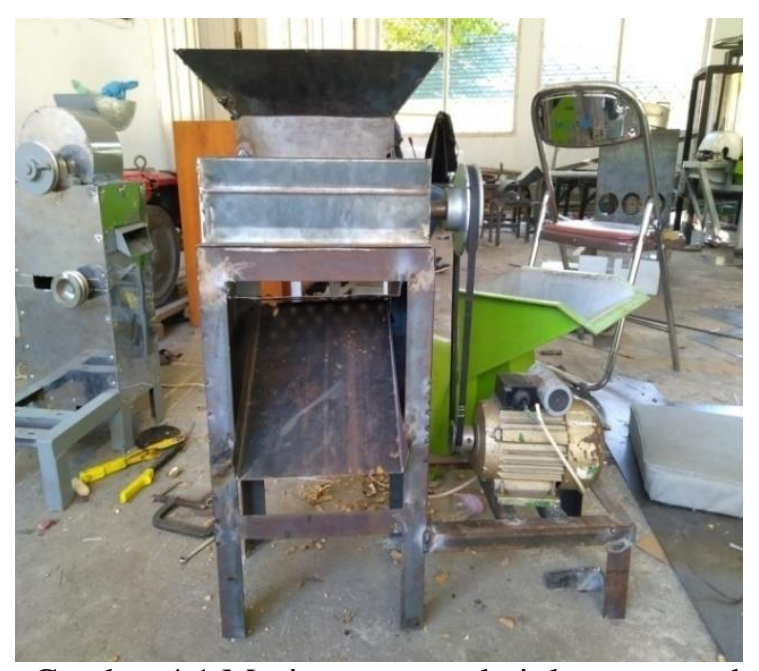

Gambar 4.1 Mesin pengupas kuit kacang tanah

Hasil rancangan konstruksi pada Gambar 4.1 diketahui bahwa mesin penggerak menggunakan motor listrik. Kemudian mekanisme penggerak yang digunakan adalah puli pengantar.

Tabel 4.1 Dimensi alat

\begin{tabular}{|l|l|}
\hline Bagian -bagian alat & Ukuran \\
\hline Tinggi alat & $54 \mathrm{~cm}$ \\
\hline Lebar alat & $68 \mathrm{~cm}$ \\
\hline Panjang saringan & $35 \mathrm{~cm}$ \\
\hline
\end{tabular}

\begin{tabular}{|l|l|}
\hline Lebar saringan & $26 \mathrm{~cm}$ \\
\hline Panjang saringan 1 & $30 \mathrm{~cm}$ \\
\hline Lebar saringan 1 & $26 \mathrm{~cm}$ \\
\hline Tinggi hopper & $21 \mathrm{~cm}$ \\
\hline Lebar hopper & $18 \mathrm{~cm}$ \\
\hline Panjang hopper & $33 \mathrm{~cm}$ \\
\hline Panjang mata pisau 2 & $31 \mathrm{~cm}$ \\
\hline Tinggi mata pisau 2 & $6 \mathrm{~cm}$ \\
\hline Panjang poros & $40 \mathrm{~cm}$ \\
\hline Diameter poros & 1 inci \\
\hline Panjang mata pisau 1 & $24 \mathrm{~cm}$ \\
\hline
\end{tabular}

Berdasarkan tabel percobaan 1 dapat di pahami bahwa bahan baku kacang tanah (input) sebanyak 200 gram menghasilkan jumlah kupasan kacang tanah pada sisi outlet biji kacang sebnayak 75 gram dan 40 gram pada posisi outlet kulit terbuang dan kulit ari. Dengan demikian dapat dipahami bahwa jumlah biji yang terkupas (output) sebanyak 115 gram, didapatkan dari percobaan jumlah hasil kacang tanah dan hasil kacang tanah yang tercampur dengan kulit ari. Sedangakan pada pengujian terhadap losses sebesar 45 gam, sehingga effesien pengupasan mesin pengupas kacang tanah dapat di hitung dengan persamaan

$$
\begin{gathered}
\text { Effesien }=\frac{\text { Output }}{\text { Input }} \times 100 \\
=\frac{115}{200} \times 100 \\
=57,5 \%
\end{gathered}
$$

Pada percobaan 1 dapat diketahui hasil akhir pengupasan kacang tanah adalah sebanyak $57,5 \%$. Sedangkan jumlah kacang tanah yang terbuang adalah sebanyak $42,5 \%$

Percobaan 2 dapat di pahami bahwa bahan baku kacang tanah (input) sebanyak 200 gram menghasilkan jumlah kupasan kacang tanah pada sisi outlet biji kacang sebesar 80 gram dan 50 gram pada posisi outlet kulit kacang. Dengan demikian dapat dipahami bahwa jumlah biji yang terkupas (output) sebanyak 130 gram, didapatkan dari percobaan jumlah hasil kacang tanah dan hasil 
kacang tanah yang tercampur dengan kulit ari. Sedangakan pada pengujian terhadap losses sebesar 30 gram, sehingga effesien pengupasan mesin pengupas kacang tanah dapat di hitung dengan persamaan

$$
\begin{aligned}
\text { Effesien } & =\frac{\text { Output }}{\text { Input }} \times 100 \\
& =\frac{130}{200} \times 100 \\
& =65 \%
\end{aligned}
$$

Pada percoban 2 dapat diketahui hasil akhir pengupasan kacang tanah adalah sebanyak $65 \%$. Sedangkan jumlah kacang tanah yang terbuang adalah sebanyak $45 \%$

Berdasarkan percobaan 3 dapat di pahami bahwa bahan baku kacang tanah (input) sebanyak 200 gram menghasilkan jumlah kupasan kacang tanah pada sisi outlet biji kacang sebesar 85 gram dan 40 gram pada posisi outlet kulit kacang. Dengan demikian dapat dipahami bahwa jumlah biji yang terkupas (output) sebanyak 125 gram, didapatkan dari percobaan jumlah hasil kacang tanah dan hasil kacang tanah yang tercampur dengan kulit ari. Sedangakan pada pengujian terhadap losses sebesar 45 gam, sehingga effesien pengupasan mesin pengupas kacang tanah dapat di hitung dengan persamaan

$$
\begin{gathered}
\text { Effesien }=\frac{\text { Output }}{\text { Input }} \times 100 \\
=\frac{125}{200} \times 100 \\
=62,5 \%
\end{gathered}
$$

Pada hasil percobaan 3 dapat diketahui bahwa hasil akhir pengupasan kacang tanah adalah sebanyak $57,5 \%$. Sedangkan jumlah kacang tanah yang terbuang adalah sebanyak $42,5 \%$

Perhitungan kapasitas pengupasan kulit kacang tanah yaitu :

Percobaan 1

$$
\begin{aligned}
& \mathrm{C}=\omega / \mathrm{t}_{-} 1 \times 360 \\
& \mathrm{C}=(0,2 \mathrm{~kg}) /(73 \text { Detik }) \times 3600 \\
& =9.8 \mathrm{~kg} / \mathrm{jam}
\end{aligned}
$$

Percobaan 2

$$
\begin{aligned}
\mathrm{C} & =\omega / \mathrm{t}_{-} 1 \times 360 \\
\mathrm{C} & =(0,2 \mathrm{gr}) /(70 \text { Detik }) \times 3600 \\
& =10.28 \mathrm{~kg} / \mathrm{jam}
\end{aligned}
$$

Percobaan 3

$$
\begin{aligned}
\mathrm{C} & =\omega / \mathrm{t} \_1 \times 360 \\
\mathrm{C} & =(0,2 \mathrm{gr}) /(75 \text { Detik }) \times 3600 \\
& =9.6 \mathrm{kgr} / \mathrm{jam}
\end{aligned}
$$

Dari hasil perhitungan didapatkan bahwa percobaan dua memiliki kapasitas yang lebih baik dibandingkan dengan percobaan satu dan tiga, hasil kapasitas percobaan dua sebesar 10,28 kg/jam. Yang berarti mesin ini dapat mengupas kulit kacang tanah sebanyak 10,28 kg dalam satu jam

\section{PENUTUP}

\section{Kesimpulan}

Beberapa kesimpulan yang dapat diambil pada proses pembuatan mesin pengupas kulit kacang tanah adalah sebagai berikut:

1. Waktu pengujian sebagian besar pengupasan kulit kacang tanah belum beroperasi dengan baik dikarenakan kecepatan putaran pada motor listrik terlalu cepat

2. Pada saat kacang tanah sudah selesai di kupas oleh mesin pengupas kulit kacang tanah, hasil pengupasan kacang tanah belum sempurna di karenakan masih banyak kacang yang terbuang

\section{Saran}

Adapun saran penulis dari beberapa yang didapat pada penelitian ini adalah sebagai berikut:

1. Perlu penambahan panjang pada saringan 1 agar supaya proses penyaringan bisa 
beroperasi dengan baik

2. Bahan yang digunakan adalah kacang tanah yang sudah dikeringkan bukan kacang tanah yang sudah di sangrai/di masak

3. Perlu perubahan pada mata pisau 1, yang tadinya mata pisau berjumlah 6 mata pisau maka harus di ubah menjadi 4 mata pisau

\section{DAFTAR PUSTAKA}

Badan Pusat Statistik 2017 "Produksi Kacang Tanah DiProvinsi Gorontalo"

Djatiharti, A. et al. (2016) 'Prosiding Seminar Nasional Inovasi Teknologi Pertanian Banjarbaru', pp. 8-17.
Girisonta (1989) 'Jenis-jenis kacang tanah'. kacang tanah menurut girisonta 1989

Hadiutomo, K. 2012. M ekanisasi Pertanian. IPB Press. Bogor. $457 \mathrm{Hal}$

Makatita Yuslanto (2013) `Mesin Pengupas Kulit Kacang Tanah`

Mashuri, M. (2017) 'Mesin Pengupas Kacang Tanah - Alat Pengupas Kacang Tanah'.

R Ekafitri 2014 .Pemanfaatan Kacang-Kacangan Sebagai Bahan Baku.

Suprapto (1993) 'Definisi Dan Manfaat Kacang Tanah' 